\title{
PENGARUH KOTORAN AYAM DAN PACLOBUTRAZOL TERHADAP JUMLAH ANAKAN DAN TINGGI BATANG PADI HITAM (Oryza sativa L.) KABUPATEN TAPANULI SELATAN
}

\author{
Romaya Sitha Silitonga ${ }^{1}$, Jumaria Nasution ${ }^{2}$ \\ 1,2 Universitas Graha Nusantara, Padangsidimpuan - Tapanuli Selatan \\ E-mail : romayasitha89@gmail.com
}

Received: 6 July 2019

Accepted: 24 September 2019

\begin{abstract}
Black rice is very potential to be expanded because the content of anthocyanin, vitamin B1, and vitamin $\mathrm{E}$ black rice is higher than brown rice or white rice. At present, black rice producers are in Java, whereas in Sumatra, South Tapanuli District, Angkola Sub-District is a new type of black rice for rice farmers, so it is necessary to introduce and cultivate. The aims of the research was to determine the effect of chicken manure and paclobutrazol concentration on the tiller number and stems height of the rice plant in Batang Angkola District, South Tapanuli. This research method used was Randomized Block Design Factorial with two factors. The first factor was application of chicken manure (C) with dosage $0 \mathrm{~g} /$ pot $3 \mathrm{~g} / \mathrm{pot}(\mathrm{C} 1), 6 \mathrm{~g} / \mathrm{pot}$ (C2) and $9 \mathrm{~g} / \mathrm{pot}(\mathrm{P} 3)$. The second factor was application paklobutrazol (P) with concentrations of $0 \mathrm{ppm}(\mathrm{P} 0), 25 \mathrm{ppm}(\mathrm{P} 1), 50 \mathrm{ppm}(\mathrm{P} 2)$ and 75 ppm (P3). Statistical analysis used Anova 5\%. If there is a difference followed by DMRT. The result showed that application of chicken manure at $9 \mathrm{~g} / \mathrm{pot}(\mathrm{C} 3)$ and paclobutrazol $75 \mathrm{ppm}(\mathrm{P} 3)$ were produce more tiller number and able to decrease height of black rice plant.
\end{abstract}

Key words : Black Rice, Chicken manure, Paklobutrazol, South Tapanuli District, Tiller number,

\begin{abstract}
ABSTRAK
Padi hitam sangat potensial dikembangkan karena kandungan antosianin, vitamin B1, dan vitamin E padi hitam lebih tinggi dari beras merah maupun beras putih. Adapun daerah penghasil beras hitam saat ini masih terdapat di daerah-daerah Pulau Jawa, sementara di Pulau Sumatera, khususnya di Kabupaten Tapanuli Selatan, Kecamatan Batang Angkola beras hitam masih tergolong tanaman padi jenis baru bagi para petani beras sehingga perlu dilakukan upaya perkenalan dan budidaya di daerah ini. Penelitian ini bertujuan mengetahui pengaruh konsentrasi kotoran ayam dan paclobutrazol terhadap jumlah anakan dan tinggi batang padi hitam yang tumbuh di Kecamatan Batang Angkola, Tapanuli Selatan. Metode penelitian yang digunakan adalah Rancangan Acak Kelompok Faktorial dengan 2 faktor. Faktor pertama, aplikasi Kotoran ayam (C) dengan dosis $0 \mathrm{~g} / \mathrm{pot}(\mathrm{C} 0), 3 \mathrm{~g} / \mathrm{pot}(\mathrm{C} 1), 6$ $\mathrm{g} /$ pot (C2) dan $9 \mathrm{~g} /$ pot. Faktor kedua, paklobutrazol (P) dengan konsentrasi 0 ppm (P0), 25 ppm (P1), 50 ppm (P2) dan 75 ppm (P3). Data dianalisis menggunakan statistik analisis variansi pada taraf kesalahan 5\%. Apabila ada beda nyata dilanjutkan dengan DMRT. Hasil penelitian aplikasi Kotoran ayam 9 g/pot (C3) dan paclobutrazol 75 ppm (P3) menghasilkan jumlah anakan lebih banyak dan dapat menekan pertumbuhan tinggi batang padi hitam yang ditanam.
\end{abstract}

Kata Kunci : Jumlah anakan, Kabupaten Tapanuli Selatan, Kotoran Ayam, Paclobutrazol, Padi hitam.

\section{PENDAHULUAN}

Tanaman padi tergolong dalam family Graminae. Padi Merupakan serelia utama penghasil beras yang dikonsumsi sebagai bahan makanan pokok oleh sebagian besar penduduk. Tanaman Padi Hitam lokal memiliki bentuk tanaman yang

tegap, tingginya bisa mencapai 2 meter. Padi beras hitam yang dihasilkan memiliki rasa dan aroma yang baik dengan penampilan yang spesifik dan unik. Kabupaten Tapanuli Selatan, budidaya beras hitam belum cukup popular oleh kalangan para petani beras, sehingga perlu memperkenalkan beras hitam yang kaya akan manfaat dan dapat meningkatkan perekonomian kepada sejumlah para petani beras yang ada di kabupaten Tapanuli Selatan khususnya yang ada di Kecamatan Batang Angkola.

Umur panen yang panjang dan produktifitas yang rendah merupakan faktor pembatas yang dapat menyebabkan minat petani untuk menanam padi lokal semakin rendah sehingga dikhawatirkan para petani padi di Kabupaten Tapanuli Selatan tidak mau menanam tanaman padi hitam. Banyaknya manfaat dengan 
mengkonsumsi beras hitam menjadi sangat penting untuk tetap mempertahankan keberlanjutan produksi padi hitam sehingga diperlukan suatu usaha untuk memperbaiki varietas padi hitam terutama dari segi umur panen, tinggi tanaman dan daya hasilnya. Penggunaan zat pengatur tumbuh dapatdilakukan untuk mengatur pola pertumbuhan tanaman dengan tujuan mempertahankan keseimbangan pertumbuhan vegetatif dan generatif, sehingga kompetisi pemanfaatan source oleh pertumbuhan vegetatif dan generatif yang mengakibatkan rendahnya assimilat yang didistribusikan ke dalam sink dapat di tekan (Serly, 2013).

Paklobutrazol merupakan salah satu retardan yang bila diberikan pada tanaman yang responsif dapat menghambat perpanjangan sel pada meristem sub apikal, mengurangi laju perpanjangan batang tanpa mempengaruhi pertumbuhan dan perkembangan daun (Tumewu dkk., 2012). Paklobutrazol bekerja dengan cara menghambat pembentukan dan kerja giberelin merangsang kerusakan giberelin sehingga konsentrasi giberelin dalam tanaman menurun. Menurut Wattimena (1989) menyatakan bahwa tanaman tidak akan respon terhadap zat pengatur tumbuh yang bersangkutan apabila tidak diberikan pada masa pekanya. Secara keseluruhan, diperoleh bahwa semakin awal paklobutrazol diberikan pada tanaman maka sifat penghambatnya akan semakin besar, sebaliknya semakin lama pakloutrazol diberikan pada tanaman maka sifat penghambatan yang ditimbulkan semakin kecil.

Kotoran ayam atau bahan organik merupakan sumber nitrogen tanah yang utama, serta berperan cukup besar dalam memperbaiki sifat fisik, kimia, dan biologis tanah serta lingkungan. Di dalam tanah, pupuk organik akan dirombak oleh organisme menjadi humus atau bahan organik tanah (Widodo, 2008). Kotoran ayam dapat digunakan sebagai pupuk organik untuk berbagai komoditas tanaman salah satunya adalah tanaman jagung karena dapat merangsang pertumbuhan tanaman jagung serta menambah kesuburan tanah yang akan berdampak pada kesuburan tanaman itu sendiri (Harsono, 2009). karena itu, peneliti ingin mengetahui pengaruh kotoran ayam dan paclobutrazol terhadap jumlah anakan dan tinggi batang padi hitam yang diharapkan membantu para petani padi agar dapat menghasilkan benih yang baik sehingga para petani padi khususnya di Kabupaten Tapanuli Selatan dapat membudidayakan tanaman padi hitam dan mendapatkan hasil produksi yang baik.

\section{BAHAN DAN METODE}

Penelitian ini dilakukan di green house desa Pintu Padang Kecamatan Batang Angkola dengan Rancangan Acak Kelompok factorial dengan 2 faktor. Faktor pertama adalah pemberian paklobutrazol $(\mathrm{P})$ dengan konsentrasi 0 (P0), 25 ppm (P1), 50 ppm (P2) atau 75 ppm (P3). Faktor yang kedua adalah pemberian kotoran ayam (C) dengan dosis $0 \mathrm{~g} /$ pot $(\mathrm{C} 0)$, 3g/pot (C1), 6g/pot (C2), atau 9g/pot (C3). Masing - masing kombinasi perlakuan dengan 4 ulangan. Sampel tanaman padi hitam Cempo ireng.

Parameter yang diamati adalah tinggi batang pada padi hitam. Analisis data dengan menggunakan ANOVA pada taraf signifikansi 5\% dan dilanjutkan dengan Uji Beda Nyata Terkecil (DMRT). Analisis ini dilakukan dengan menggunakan Software SPPS untuk mempelajari hubungan antara pemberian paclobutrazol dan kotoran ayam terhadap tinggi batang tanaman padi hitam.

\section{Tinggi Batang}

HASIL DAN PEMBAHASAN

Tabel.1 Tinggi Tanaman Padi Hitam Hasil Perlakuan Konsentrasi Paklobutrazol dan Kotoran Ayam

\begin{tabular}{|c|c|c|c|c|}
\hline \multirow{2}{*}{ Paclobutrazol (P) } & \multicolumn{4}{|c|}{ Kotoran Ayam (C ) } \\
\cline { 2 - 5 } & C0 & C1 & C2 & C3 \\
\hline P0 & $83,500^{\mathrm{a}}$ & $79,542^{\mathrm{a}}$ & $63,625^{\mathrm{a}}$ & $87,167^{\mathrm{a}}$ \\
\hline P1 & $60,875^{\mathrm{a}}$ & $80,417^{\mathrm{a}}$ & $80,667^{\mathrm{a}}$ & $81,417^{\mathrm{a}}$ \\
\hline P2 & $82,917^{\mathrm{a}}$ & $80,167^{\mathrm{a}}$ & $81,917^{\mathrm{a}}$ & $81,167^{\mathrm{a}}$ \\
\hline P3 & $54,583^{\mathrm{a}}$ & $79,167^{\mathrm{a}}$ & $57,125^{\mathrm{a}}$ & $60,375^{\mathrm{a}}$ \\
\hline
\end{tabular}

Keterangan : Angka yang diikuti oleh huruf yang sama menunjukkan perbedaan yang tidak nyata berdasarkan uji DMRT 5\%

Dari Hasil Tabel 1. didapatkan bahwa pada konsentrasi Paclobutrazol 75 ppm (P3) cenderung terjadi penurunan tinggi tanaman padi hitam dibandingkan Paclobutrazol pada konsentrasi 0 ppm (P0), Paclobutrazol pada konsentrasi 25 ppm (P1), Paclobutrazol pada konsentrasi 50 ppm (P2).

Pada dosis kotoran ayam $0 \mathrm{~g} / \mathrm{pot}(\mathrm{C} 0)$ yaitu 54,583 dan pada dosis kotoran ayam $3 \mathrm{~g} / \operatorname{pot}(\mathrm{C} 1)$ yaitu 79,167 dan pada dosis kotoran ayam $6 \mathrm{~g} / \mathrm{pot}$ (C2) yaitu 57,125 serta pada dosis kotoran ayam $9 \mathrm{~g} /$ pot (C3) yaitu 60,375, disini terlihat bahwa penurunan tinggi batang terjadi pada dosis 
kotoran ayam 9 g/pot (C3) pada konsentrasi 75 ppm (P3) paclobutrazol, hal ini dikarenakan semakin tinggi konsentrasi paklobutrazol dan

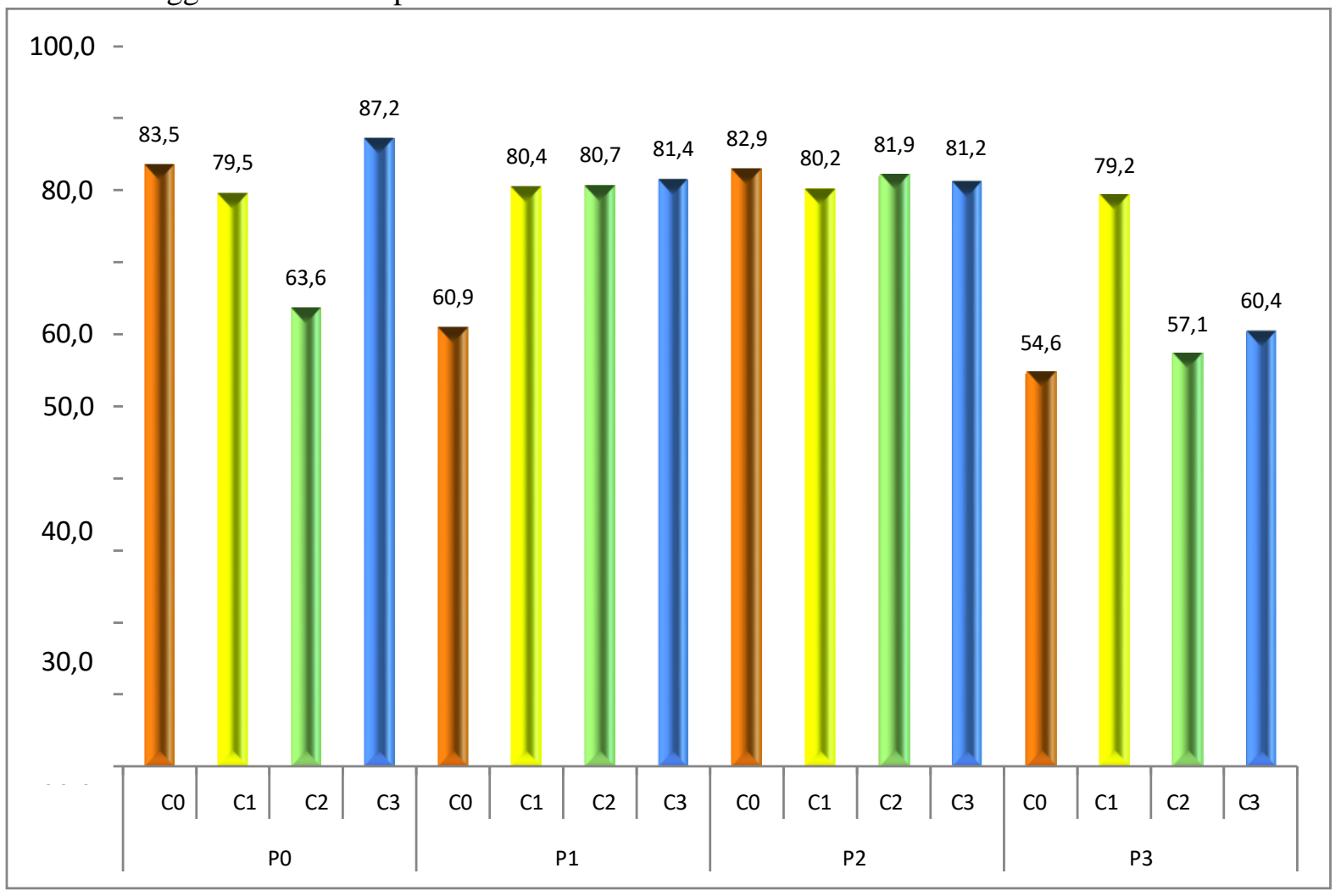

dosis kotoran ayam yang diberikan maka tinggi batang tanaman padi hitam semakin berkurang, seperti terlihat pada Gambar 1.

Gambar 1. Perbandingan rata-rata tinggi tanaman Gambar 2. Perbandingan rata-rata Jumlah Anakan

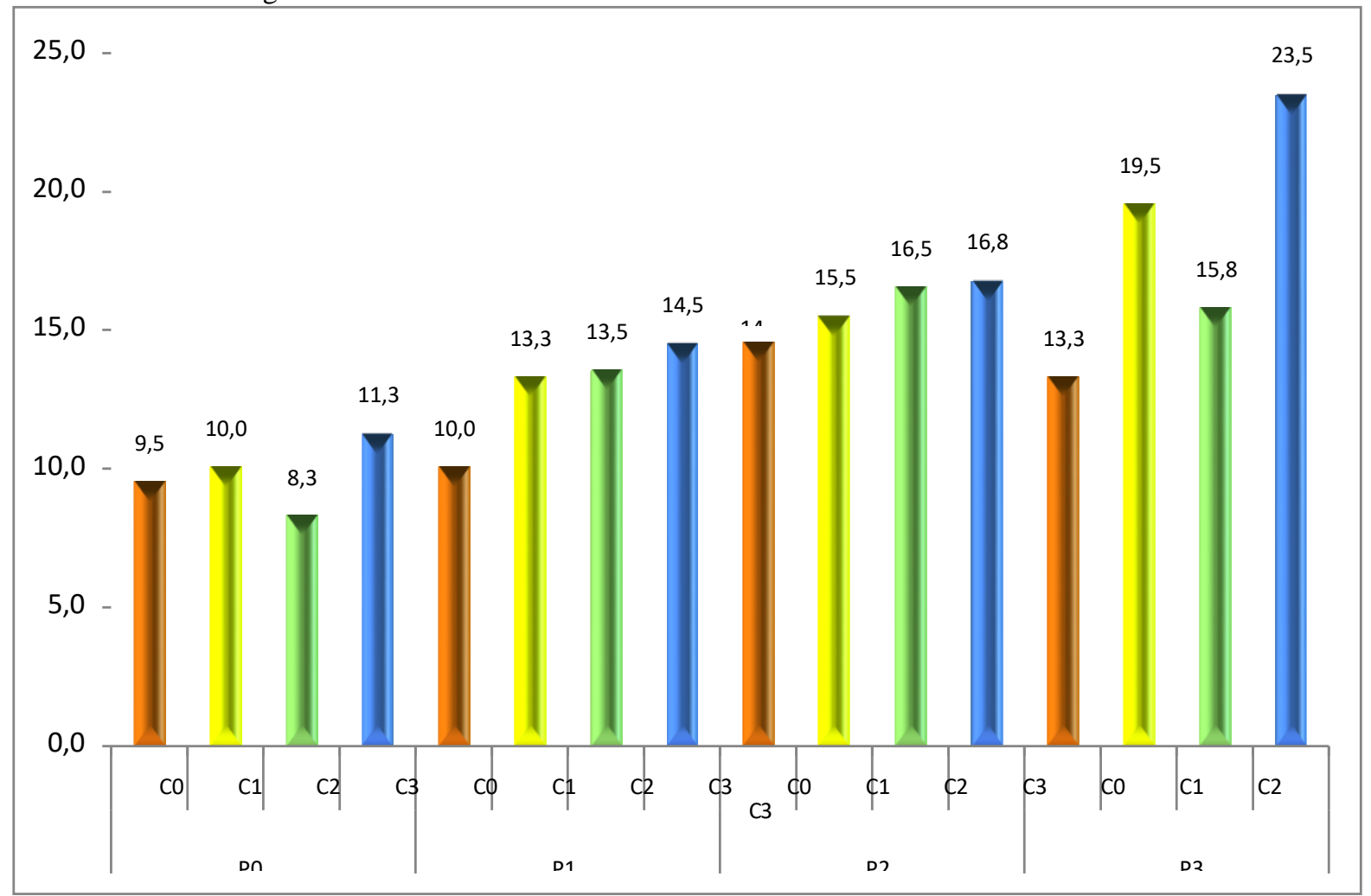




\section{Jumlah Anakan}

Tabel.2 Jumlah Anakan Tanaman Padi Hitam Hasil Perlakuan Konsentrasi Paklobutrazol dan Kotoran Ayam

\begin{tabular}{|c|l|l|l|c|}
\hline \multirow{2}{*}{$\begin{array}{c}\text { Paclobutrazol } \\
(P)\end{array}$} & \multicolumn{4}{|c|}{ Kotoran Ayam (C ) } \\
\cline { 2 - 5 } & $\mathrm{C} 0$ & $\mathrm{C} 1$ & $\mathrm{C} 2$ & $\mathrm{C} 3$ \\
\hline $\mathrm{P} 0$ & $9,500^{\mathrm{a}}$ & $10,000^{\mathrm{ab}}$ & $8,250^{\mathrm{a}}$ & $11,250^{\mathrm{ab}}$ \\
\hline $\mathrm{P} 1$ & $10,000^{\mathrm{ab}}$ & $13,250^{\mathrm{ab}}$ & $13,500^{\mathrm{ab}}$ & $14,500^{\mathrm{ab}}$ \\
\hline P2 & $14,500^{\mathrm{ab}}$ & $15,500^{\mathrm{ab}}$ & $16,500^{\mathrm{ab}}$ & $16,750^{\mathrm{ab}}$ \\
\hline P3 & $13,250^{\mathrm{ab}}$ & $23,500^{\mathrm{ab}}$ & $15,750^{\mathrm{ab}}$ & $23,500^{\mathrm{a}}$ \\
\hline
\end{tabular}

Keterangan : Angka yang diikuti oleh huruf yang sama menunjukkan perbedaan yang tidak nyata berdasarkan uji DMRT 5\%

Dari Hasil Tabel 2. didapatkan bahwa pada konsentrasi Paclobutrazol 75 ppm (P3) cenderung menghasilkan jumlah anakan lebih banyak dibandingkan Paclobutrazol pada konsentrasi 0 ppm (P0), Paclobutrazol pada konsentrasi $25 \mathrm{ppm}$ (P1), Paclobutrazol pada konsentrasi 50 ppm (P2).

Pada dosis kotoran ayam $0 \mathrm{~g} /$ pot $(\mathrm{C} 0)$ yaitu 13,250 dan pada dosis kotoran ayam $3 \mathrm{~g} / \operatorname{pot}(\mathrm{C} 1)$ yaitu 23,50 dan pada dosis kotoran ayam $6 \mathrm{~g} / \mathrm{pot}$ (C2) yaitu 15,750 serta pada dosis kotoran ayam $9 \mathrm{~g} /$ pot (C3) yaitu 23,50, disini terlihat bahwa kenaikan jumlah anakan terdapat pada dosis kotoran ayam 9g/pot (C3), hal ini dikarenakan semakin tinggi dosis kotoran ayam yang diberikan maka jumlah anakan yang didapat semakin banyak, seperti terlihat pada Gambar 2 .

\section{PEMBAHASAN}

Dari hasil data yang didapatkan pada Tabel 1 dan Gambar 1. bahwa perlakuan Paclobutrazol berpengaruh nyata pada variabel tinggi tanaman. $\mathrm{Hal}$ ini dikarenakan aplikasi paklobutrazol dapat menghambat sintesis giberelin tetapi meningkatkan aktivitas sitokinin yang berperan dalam deferensiasi dan pembelahan sel sehingga menyebabkan ketebalan batang tanaman padi hitam meningkat namun tidak memiliki interaksi antara paclobutrazol dan kotoran ayam. Aplikasi paklobutrazol juga dapat meningkatkan ketahanan rebah tanaman padi sampai $20 \%$ dan 37\% (Sinniah dkk., 2011; Na dkk., 2011).

Tinggi tanaman padi hitam umumnya mencapai $200 \mathrm{~m}$, tetapi dengan aplikasi pakobutrazol dapat menurunkan dan mempertebal diameter batang sehingga meningkatkan ketahanan tanaman padi hitam terhadap kerebahan. pemberian pupuk, baik jenis atau dosis memengaruhi pertumbuhan dan

hasil tanaman padi. Namun demikian, menurut Rahayu \& Harjoso (2011), pengaruh terhadap pertumbuhan tanaman bukan hanya karena faktor pemberian pupuk tetapi faktor varietas juga sangat berpengaruh. Sedangkan Hoque dkk., (2003) dan Warda (2011) menyatakan bahwa tinggi tanaman sangat dipengaruhi varietas dan galur yang memiliki adaptasi yang lebih baik terhadap lingkungan.

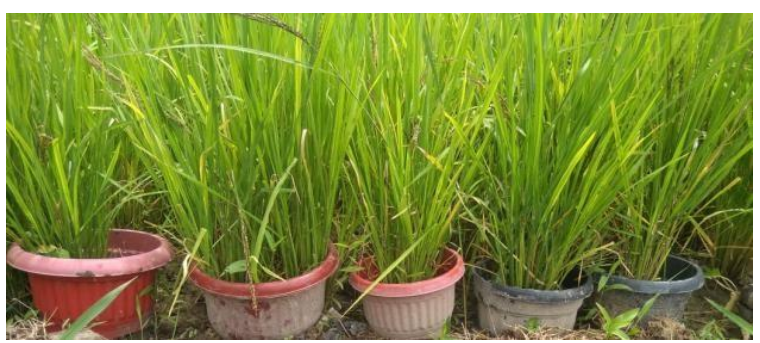

Gambar 3. Tinggi tanaman Padi Hitam (Pot Berwarna Merah) yang hampir memiliki tinggi dengan Padi biasa (Pot Berwarna Hitam)

Secara kuantitatif terlihat bahwa dosis pupuk kandang menghasilkan jumlah anakan tanaman padi yang berbeda (Tabel 2). Pemberian perlakuan jenis pupuk kandang berpengaruh nyata terhadap jumlah anakan tanaman padi hitam (Gambar 2). Hal ini disebabkan karena dalam proses pembentukan anakan tanaman lebih banyak membutuhkan unsur P. Menurut Handojo (1991), salah satu fungsi unsur hara $P$ adalah untuk merangsang akar dan batang tanaman padi serta memperbesar pembentukan anakan. Kandungan hara pada pupuk kandang kotoran ayam lebih banyak dibandingkan pupuk kandang kotoran sapi dan kambing. Dari Tabel 2. Beda nyata yang dihasilkan pada jumlah anakan menunjukkan adanya interaksi antara dosis kotoran ayam dengan tanaman padi hitam.

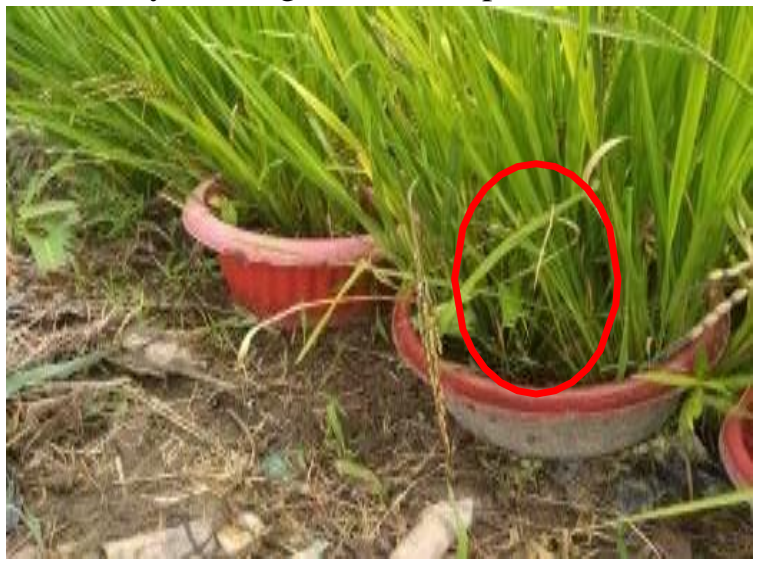


Gambar 4. Jumlah Anakan Pada Padi Hitam Selama Masa Panen (120 hari)

\section{KESIMPULAN}

Aplikasi Paclobutrazol pada konsentrasi 75 ppm (P3) dan dosis kotoran ayam 9 g/pot memiliki pengaruh terhadap penurunan tinggi batang dan jumlah anakan pada tanaman padi hitam.

\section{UCAPAN TERIMAKASIH}

Peneliti mengucapkan terimakasih banyak kepada RISTEK DIKTI karena telah memberikan dana hibah pada penelitian ini. Peneliti juga mengucapkan terimakasih banyak kepada masyarakat Pintu Padang, Kabupaten Batang Angkola karena telah membantu dalam proses penyelesaian penelitian ini serta kepada partner/teman penelitian ibu Jumaria dan adik saya Risky Tumanggor karena telah memberikan waktu dan tenaganya dalam proses penyelesaian penelitian ini.

\section{DAFTAR PUSTAKA}

Handojo, D. D. 1991. Pupuk dan Pemupukan. Petunjuk dan Teknis Usaha Tani Padi- Itik-Ikan di Sawah. PT Aries Lima, Jakarta

Harsono, 2009. Kapita Selekta Neurologi. Cetakan ketujuh. Yogyakarta. Gadjah Mada University Press

Hoque, M.M., Moynul, M., Hossain, M.M., Khan, M.R.H., Khalequzzaman, K.M. \& Karim, S.M.R. 2003. Effect of varieties of rice and weeding on weed growth and yield of transplant Aman rice. Asian Journal of Plant Sciences, 2(13), 993-998.Makassar

Na, C.L Hayamen, M. Khan, and Lee, I.I. 2011. Influence of prohexadion-calcium, tripenexapac-ethyl and hexaconezole on lodging characteristic and GA biosyintesis of Rice. J. Biotech. 60:13097-13106

Rahayu, A. Y. \& Harjoso, T. 2011. Aplikasi abu sekam pada padi gogo (Oryza sativa L.) terhadap kan-dungan silikat dan prolin daun serta amilosa dan protein biji. Journal of Biota, 16(1), 48-55.

Serly. 2013. Respon Pertumbuhan Dan Produksi Ubi Jalar (Ipomoea batatas L.) Yang Diaplikasi Paklobutrazol Dan Growmore 6-30-30. Tesis Program Pascasarjana. Universitas Hasanuddin.

Sinniah, U. A. Wahyuni, S.Syahputra, B.S.A. and Gantait, S,. 2012. Aplication potensial retardant for lodging resistance in derect seeded rice (Oryza sativa .L). Can. J. plant. Sci. 92:13-18. 